\title{
Can Employee Share-Ownership Improve Employee Attitudes and Behaviour?
}

\author{
Dermot McCarthy[1], \\ Department of Accounting and Finance, \\ Business School, \\ Bournemouth University, \\ UK. \\ Email: dmccarthy@bournemouth.ac.uk \\ Eoin Reeves, \\ Department of Economics, \\ Kemmy Business School, \\ University of Limerick, \\ Ireland. \\ Email: eoin.reeves@ul.ie \\ Tom Turner, \\ Department of Personnel and Employee Relations, \\ Kemmy Business School, \\ University of Limerick, \\ Ireland. \\ Email: tom.turner@ul.ie
}

Important note: Contact corresponding author before citing this work. 


\title{
Can Employee Share-Ownership Improve Employee Attitudes and Behaviour?[1]
}

\begin{abstract}
Purpose: To examine the outcomes of a substantial broad-based employee share-ownership scheme for employee attitudes and behaviour in a privatised firm.

Methodology: Results are based on a survey of 711 employees in Eircom, an Irish telecommunications firm, which is 35 percent employee-owned.

Findings: The ESOP has created sizable financial returns and has had extensive influence in firm governance at the strategic level. However, findings show only a limited impact on employee attitudes and behaviour. This is attributed to a failure in creating a sense of employee participation and line of sight between employee performance and reward.

Originality: Little research has examined the impact of a large employee shareholding on attitudes and behaviour within a public-quoted firm. The substantial and unparalleled size of the Eircom ESOP presented a unique opportunity to conduct such a study.

Policy implications: The aim of employee share-ownership often includes aligning employee objectives with those of other shareholders, and thus improving labour performance. The findings in this study highlight a need to provide employees with a sense of ownership and control. Findings also question the assumption that where employees have a substantial shareholding, they will focus on securing the long-term prospects of the firm.
\end{abstract}

Keywords: employee share-ownership; employee attitudes and behaviour, employee participation, privatisation

Category: research paper

\section{Introduction}

In recent years there has been substantial growth in the number of employee shareownership schemes throughout Europe, with the number of schemes expected to double over the next five to ten years (Mathieu, 2007). Many countries have incorporated employee shareownership as part of their privatisation programmes, with the aim of creating closer managementemployee relations, improving employee performance, and reducing opposition to firm reform (Gianaris, 1996). However, the long-term success of employee share-ownership in terms of performance is dependent on subsequent changes in employee attitudes and behaviour (Freeman, 2007; Kalmi et al., 2005). Research in the US indicates that in closely held firms (e.g. family businesses), employee share-ownership is consistently associated with increased firm performance (Rosen, 2007). However, few studies have examined the impact on performance in large publiclyquoted firms, and those studies that have been conducted provide inconsistent findings. Rosen (2007) suggests that these inconsistent findings are due to the initial rationale for establishing such schemes and relatively small percentage of firm stock (often less than 5 percent) owned by employees.

D'Art and Turner (2006) estimate that in 2005 there was approximately 400 operational employee share-ownership schemes in Ireland. Although growth in the number of schemes in the private sector has been modest, it has played a significant role in Irish public-sector reform. 
The establishment of the Eircom ESOP in 1998 was a significant development in the use of share-ownership in Irish public-sector reform. This ESOP, which secured employees an initial 14.9 percent shareholding, was used to facilitate employee and trade union cooperation in firm restructuring and privatisation. Given its significant shareholding, the Eircom ESOP has been in position to significantly influence strategic decision-making within the firm, and to create substantial financial returns for its participants. Based on a survey of Eircom employees, this paper examines if the ESOP has brought about an improvement in employee attitudes and behaviour. It can be argued that such a substantial ESOP ought to create a real sense of employee ownership, thereby improving employee attitudes and behaviour (Pendleton et al., 1995).

\section{The Eircom ESOP}

Eircom (formerly Telecom Éireann) was established in 1984 as a state-owned monopoly provider of telecommunication services in Ireland. In the mid-1990s, the firm faced a number of challenges arising from market liberalisation and rapid technological development. As a result, the firm introduced changes in management, restructured operations around five market-based business units, and entered a strategic alliance[2].

In 1997 the firm's new management team negotiated an agreement with trade unions to reduce operating costs and reform work practices (Telecom-Éireann, 1997). In exchange for agreeing to these measures, employees received a cost-free five percent shareholding through the Eircom ESOP. The agreement also allowed the ESOP to purchase a further 9.9 percent shareholding at a discounted price when the government floated the remainder of its shareholding on the stock exchange in July 1999. The ESOP raised the required capital (€241 million) through firm contributions and a loan that was repaid through a profit-sharing scheme.

The structure of the Eircom ESOP centres on a limited liability trust, whose board of directors is dominated by nominees from the firm's trade unions. The trust retains and exercises ownership rights over the ESOP's shareholding on behalf of its participants, and also nominates representatives to Eircom's board of directors (initially two directors). Under tax legislation, once the shares have been retained for a period of three years, it is at the discretion of the trust to make annual tax-free distributions of up to $€ 12,700$ to each participant.

The ESOP has played a significant role in the governance of Eircom, particularly in relation to changes in firm ownership. In 2001, competing takeover bids for Eircom were launched by two Irish consortiums, Valentia Telecommunications and e-Island. Its substantial shareholding gave the ESOP a decisive influence over which bid would succeed, and following intense negotiations the ESOP decided to support the bid of Valentia. In return for supporting the takeover and a subsequent refinancing package for the firm, the ESOP was allowed to increase its shareholding to nearly 30 percent and number of board-level representatives to three. As highlighted by a prominent trade-unionist and ESOP director:

"The role played by the unions and the ESOP in the takeover of Eircom was unquantifiable. Was there ever a bunch of workers in the world had such influence over who was going to own their company?"

(Hastings, 2003, p.6)

Eircom was refloated on the stock exchange in 2004. However, in 2006 the firm was again taken over by an Australian investment firm, Babcock and Brown. The ESOP again played a 
decisive role in this takeover, and thereby increased its shareholding to 35 percent and retained its three board-level representatives.

Alongside the ESOP, other changes in firm governance were introduced to increased employee participation. Most significantly, a formal partnership structure was established between firm management and trade unions to help implement the reforms that would accompany privatisation (Telecom-Éireann, 1997). The development of such structures reflected the broader emphasis on workplace partnership in the social partnership agreements negotiated at national level. Workplace partnership became a declared objective of the Irish government, trade unions and employers organisations in the Partnership 2000 Agreement (Nesc, 1996: 39-43; O'Donovan, 1999: 108-22). However, the benefits of workplace partnership for employees is a contested issue (Stuart and Lucio, 2005). Advocates stress the possibility of 'mutual gains' for the stakeholders in the organisation by facilitating increased employee involvement in a climate of cooperation and trust (Ackers and Payne, 1998; Kochan and Osterman, 1994). Alternatively, critics emphases the possibility that unions will be weakened and employees subject to greater surveillance and work intensification (Kelly, 2001; Taylor and Ramsay, 1998). In practice the processes and outcomes of workplace partnership are influenced by a complex set of factors such as the motivation of unions and management to engage in a partnership process, the extant organisational culture and the prevailing economic environment (Lucio and Stewart, 2004). With its substantial employee share-ownership, the Eircom ESOP can plausibly be expected to create a greater sense of participation among employees and reinforced the partnership process.

\section{Impact of share-ownership on employee attitudes and behaviour}

To probe this issue further in the context of the Eircom ESOP we adopt the model of Klein (1987). In general, studies on the impact of employee share-ownership schemes lend little support to claims that they can have a direct positive impact on employee attitudes and behaviour, or that they directly encourage employees to identify more closely with the company (Saunders and Harris, 1994). Similar conclusions can be drawn from studies of employee share-ownership schemes that are introduced in the context of privatisation (see for example O'Connell Davidson, 1993; Saunders and Harris, 1994; Smith, 2009). The broad thrust of these findings was described by Smith (2009). In his study of the process of culture change within Durham National Savings, before and after the introduction of a public-private partnership, he reports:

"The majority of workers interviewed simply saw this as a detached financial bonus, and it did not result in them feeling any sense of affinity to the company. Indeed, some sold their shares as soon as the three year "no sell' clause had expired"

(Smith, 2009: p.20)

Klein (1987) identifies three possible routes through which share-ownership impacts on employee attitudes and behaviour (see figure 1). First, the intrinsic route is based on the premise that share-ownership alone is sufficient to influence employee attitudes and behaviour. However, in her own study of 37 US firms with ESOPs, Klein (1987) found little empirical evidence to support the intrinsic model. A number of other studies also indicate that share-ownership has a greater effect on attitudes and behaviour when employees feel it brings greater financial returns or a greater sense of control over workplace decision-making (see for example Freeman et al., 2004; Gittell et al., 2004; Kruse et al., 2004; Pendleton et al., 2001). These findings lend support to Klein's further two possible routes.

\section{Figure 1: Causal model}

[pic] 
The second route, the instrumental route, has been the subject of much research, and proposes an indirect relationship that results from the shareholding creating a sense of ownership and participation in firm decision-making among employees (Ben-Ner and Jones, 1995; Pendleton et al., 1998). Creating a sense of ownership it is argued has the potential to align the objectives of employees and other shareholders, giving employees a greater sense of belongingness and thereby increasing their commitment to the firm (Long, 1980). To achieve this, it is important that management recognise employees as firm owners and adopt a culture of shared information and participation in decision-making at all levels within the firm (Blasi et al., 2003; Gianaris, 1996; Kaarsemaker and Poutsma, 2006). This can involve management drawing more fully on employee knowledge and expertise, thereby allowing employees to view their individual contribution as important in the context of firm performance (Blasi et al., 2004; Sesil et al., 2002). Extant empirical research highlights the potential for employee participation in decision-making, particularly at the workplace-level, to enhance performance. However, research also indicates many share-ownership schemes fail to create a greater sense of ownership among employees (see for example Freeman et al., 2004; Gittell et al., 2004; Kruse et al., 2004; Pendleton et al., 1998; Rooney, 1988). In such cases, share-ownership has been found to have little impact on employee attitudes and behaviour.

Finally, the extrinsic route also posits an indirect relationship resulting from whether employees perceive a clear line of sight between their work-effort and the financial returns they receive from the share-ownership scheme. Employees can be substantial beneficiaries of shareownership schemes, often receiving their initial shareholding at a discounted price, along with financial returns that qualify under tax incentives. However, the free-rider problem and riskaverse nature of employees can limit the ability of share-ownership in providing effective groupbased financial incentives (Ben-Ner and Jones, 1995; Blasi et al., 1996; Conte and Kruse, 1991). Effective incentives assume managers can freely observe individual employee effort, which is often not possible given the existence of team structures and subsequent information asymmetry (Alchian and Demsetz, 1973). Furthermore, while employees invest a great deal of nondiversifiable human-capital in the firm, variations in share value are affected by issues other than employee effort (Beatty and Zajac, 1994; Grossman and Hart, 1980; Hart, 1983). For these reasons employees may be unwilling to allow a large proportion of their income to depend on performance related measures, and have difficulties in identifying a direct link between their workeffort and financial returns (Jensen and Murphy, 1990; Rosen, 2007). Nevertheless, empirical research on the extrinsic view indicates that the financial return generated through shareownership has a positive relationship with employee performance, although this relationship is not strong (Buchko, 1993). This would indicate that risk-aversion and the free-rider problem do not negate the impact of financial returns on employee attitudes and behaviour. The perceived risk employees associate with share-ownership may be reduced by the fact returns often come in addition to existing wages and not as a substitute (Freeman, 2007). Furthermore, the free-rider problem may be countered by the establishment of a more cooperative culture in which employees exert greater peer pressure and monitor their co-workers' behaviour (Blasi et al., 2004).

Together, the instrumental and extrinsic routes propose that to realise the full potential of employee share-ownership, it is necessary for two criteria to be met. First, employees must be given a substantial financial return, which each feels is directly related to their individual performance. Second, employee share-ownership should be implemented as part of a strategy aimed at promoting a firm culture of employee participation and employee-management cooperation. Indeed where employees report little improvement in their ability to participate, they 
may experience a sense of disappointed expectations that can have negative outcomes for employee attitudes and behaviour (Ben-Ner and Jones, 1995).

\section{Research methods}

This paper examines the impact of a substantial broad-based ESOP on employee attitudes and behaviour. Based on the causal model suggested above, it also examines the mechanisms (instrumental and extrinsic routes) through which employee share-ownership impacts on employee attitudes and behaviour.

The data used is based on a survey of Eircom employees conducted in February 2007, just over 9 years after the establishment of the ESOP. The survey used closed format questions and was conducted online with the support of both firm management and trade unions. A representative sample of 1,000 employees was surveyed and the response rate was just over 70 percent $(\mathrm{n}=711)$. A stratified sampling approach was adopted, dividing employees by geographical region and business area. Specifically, the survey sought data in relation to the following variables:

Changes in employee participation in decision-making: a nine item measure using a seven-point scale. Four items related to the operational level (OpPart), while five items related to the departmental and strategic-level (StratPart) (see table 1).

Changes in employee attitudes: a measure using six statements and a seven-point Likert scale (see table 3).

Changes in employee citizenship behaviour: a measure using three statements and a seven-point Likert scale (see table 3).

ESOP membership: a dichotomous dummy variable used to establish membership or nonmembership.

Control variables: gender and occupational group (Retail/Other).

The data was analysed using OLS regression and Appendix 1 shows descriptive statistics, reliability measures, and a correlation matrix for each variable. The reliability of each measure was assessed using Cronbach's Alpha (?), with all measures having values above 0.7.

\section{Employee participation in firm decision-making}

While the ESOP has played a crucial role in Eircom's strategic decision-making processes (see section 2), it may also have acted to create a greater sense of participation among employees and reinforced the partnership process. In our survey, a majority of employees report either a decrease or an unchanged level of participation since the introduction of the ESOP (table 1).

With regard to operational issues, 16 percent of respondents reported an increase in employee participation, while 53 percent reported deterioration in employee participation. At the strategic-level (here the ESOP could be expected to have its greatest influence) 63 percent of employees reported a decrease in their level of participation and only 14 percent indicated an improvement in employee participation.

Table 1: Changes in employee participation (percentages)

Operational level

Manner in which they do their work

Hours they work

Pay/benefits they receive

\begin{tabular}{|l|l|l}
$\begin{array}{l}\text { More say } \\
(1-3)\end{array}$ & $\begin{array}{l}\text { Neither } \\
(4)\end{array}$ & $\begin{array}{l}\text { Less say } \\
(5-7)\end{array}$ \\
20 & 34 & 46 \\
15 & 35 & 50 \\
18 & 23 & 59
\end{tabular}




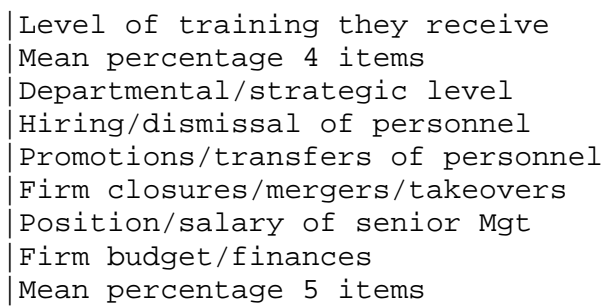

\begin{tabular}{|l|l|l}
12 & 30 & 58 \\
16 & 31 & 53 \\
8 & 27 & 65 \\
19 & 26 & 66 \\
18 & 23 & 58 \\
18 & 18 & 64 \\
14 & 22 & 60 \\
& 23 & 63
\end{tabular}

Notes: employees presented with scale 1 (much more say) to 7 (much less say)

It appears that the establishment of the ESOP has not translated into a perception of increased participation in decision-making among employees. Indeed, many employees reported a significant decrease in their level of participation. This may reflect a sense of disappointed expectations among employees. These results provide little support for the assumption that the ESOP would strengthened the partnership process for employees in Eircom.

\section{Employee financial returns}

To date the ESOP has made 12 financial distributions to its participants (table 2). The first distribution occurred following the takeover of Eircom by Valentia. In this distribution, each full participant [2] received 7,270 Vodafone ordinary shares [3]. While under the ownership of Valentia, Eircom was not quoted on the stock market and participants could not realise the value on ordinary shares. Therefore, in the subsequent two distributions redeemable preference shares were used. Following the return of Eircom to the stock market in 2004, two distributions were held in which for the first time participant were given an opportunity to receive Eircom ordinary shares. Following the takeover by Babcock and Brown in 2006, the six most recent distributions again relied on the use of redeemable preference shares. These most recent distributions have significantly reduced the trust's holdings of preference shares, but have allowed it to maintain its 35 percent ordinary share holding in the firm.

Table 2 ESOP distributions made to date

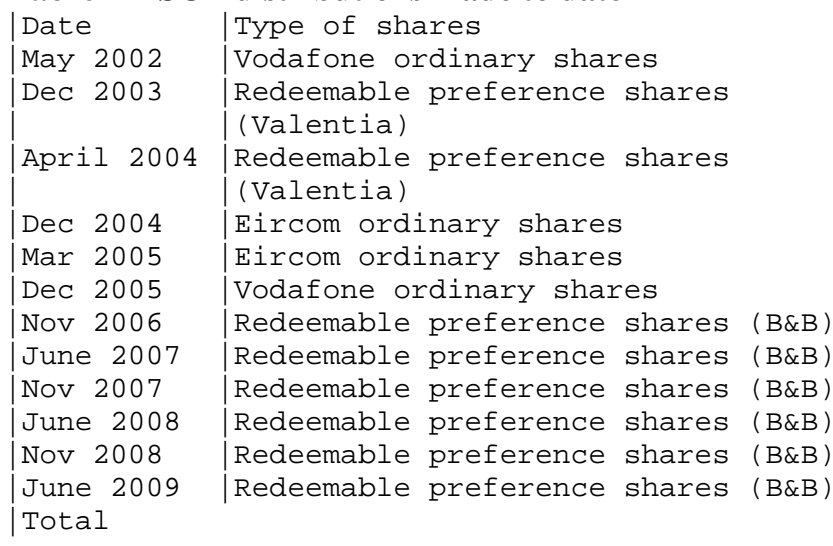

\begin{tabular}{|c|c|}
\hline $\begin{array}{l}\text { No. of shares * } \\
7,270 \\
6,872\end{array}$ & $\begin{array}{l}\text { Cash value }(€) \\
11,904 \\
6,872\end{array}$ \\
\hline 6,872 & 6,872 \\
\hline 3,307 & $5,556 \dagger$ \\
\hline 3,307 & $6,614 \dagger$ \\
\hline 2,688 & 4,781 \\
\hline 13,701 & 8,073 \\
\hline 13,714 & 8,080 \\
\hline 4,619 & 4,619 \\
\hline 13,748 & 7,022 \\
\hline 5,065 & 5,065 \\
\hline 3,916 & 2,000 \\
\hline & 77,458 \\
\hline
\end{tabular}

Source: www.esop.Eircom.ie

*figures represent distributions per full participant, after giving one year's continuous service prior to the establishment of the ESOP $\dagger$ Value based on share price on day of distribution

Overall between 2002 and 2009 employees who are full participants of the ESOP received benefits to the nominal value of approximately $€ 77,458$. Moreover, despite paying out these substantial benefits to participants, the ESOP still retains a 35 percent shareholding in the firm.

\section{The role of the ESOP in determining employee attitude and behaviour}


Employee share-ownership can be expected to align the objectives of employees with those of the firm and its management, and thus stimulate greater employee performance. As the causal model suggested, this can be brought about through creating a greater since of participation in firm decision-making and/or a direct line of sight between employee effort and financial returns (figure 1). It is evident that the Eircom ESOP has been associated with significant outcomes in terms of both employee participation and financial returns. Using the employee survey we examine whether these have significantly altered employee attitudes and behaviour. It should however be noted that the introduction of the Eircom ESOP occurred as part of the firm's commercialisation and privatisation, and therefore observed changes in attitudes and behaviour could be influenced by extraneous variables.

Table 3 Changes in employee attitude and behaviour

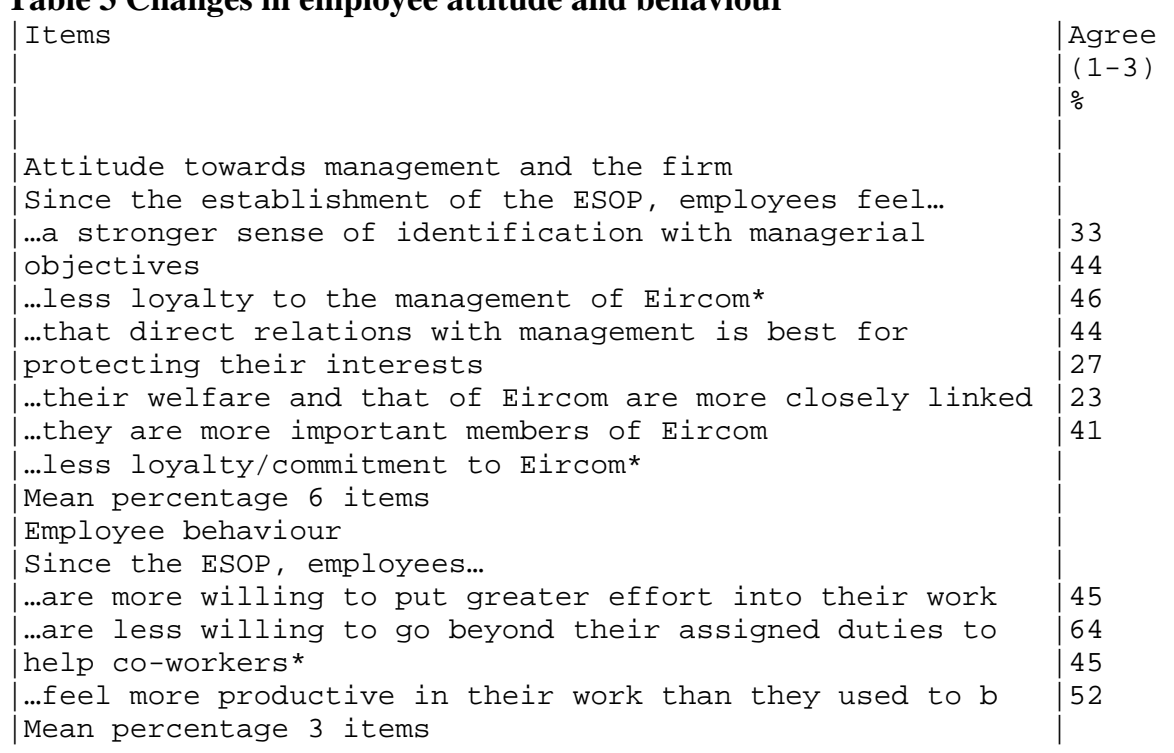

\begin{tabular}{|l|l|}
$\begin{array}{l}\text { Neither } \\
(4)\end{array}$ & Disagree \\
$\%$ & $(5-7)$ \\
& \% \\
24 & \\
28 & 43 \\
24 & 29 \\
17 & 30 \\
19 & 39 \\
23 & 54 \\
23 & 54 \\
& 36 \\
& \\
24 & \\
16 & 31 \\
24 & 31 \\
21 & 27
\end{tabular}

Notes: employees presented with scale 1 (strongly agree) to 7 (strongly disagree)

*Item scores have been reversed

Two sets of items are used to measure changes in attitudes and behaviour (table 3). Essentially attitudinal items measure the extent of changes in employee commitment to the firm and the extent to which their objectives are aligned with those of the firm and its management. A significant number of employees agreed that their welfare and that of the firm has become more closely aligned (44 percent) and that more direct relations with management are the best means of protecting employee interests (46 percent). Furthermore, a large proportion of employees disagreed when asked if there has been a reduction in their level of loyalty towards either management (44 percent) or the firm (54 percent). On the other hand, a large proportion of employees also disagree when asked if they identify more with managerial objectives (43 percent) or feel they have become more important members of the firm (54 percent). Overall, taking the average of the six items, 41 percent of respondents agreed that there has been a positive change in employee attitudes, while 36 percent disagreed and 23 percent reported no change. Thus a majority of the employees surveyed reported either no change or a negative shift.

On the other hand, reported changes in respondents' behaviour appear to be more positive. On average, the majority (52 percent) of respondents reported an improvement in employee performance (mean for 3 items). When asked if their willingness to go beyond assigned duties has deteriorated, the majority (64 percent) or respondents disagreed. Furthermore, 45 
percent of respondents agreed that they are more willing to put greater effort into their work and that they are more productive in their work.

The causal model proposed that the effect of the ESOP on attitudes and behaviour will depend on the ability of the ESOP to create a sense of employee participation in firm decisionmaking and/or an effective link between employee financial wellbeing and their performance. To test these relationships, table 4 shows the results of a regression analysis, in which reported changes in employee attitudes and behaviour are dependent variables.

To assess the impact of employee participation, we use changes in employees' experience of participation at both the operational (OpPart) and departmental/strategic (StratPart) levels as independent variables. To examine the financial incentive factor, a dummy variable (ESOP) is used to distinguish between employees who are members of the ESOP and those who are not. It should be noted that the number of respondents who are not members of the ESOP is relatively small $(n=44)$. Given the significant level of correlation between the measures of change in operational and strategic-level participation $(r=.65$, see appendix 1$)$ separate regression analyses are conducted for both variables.

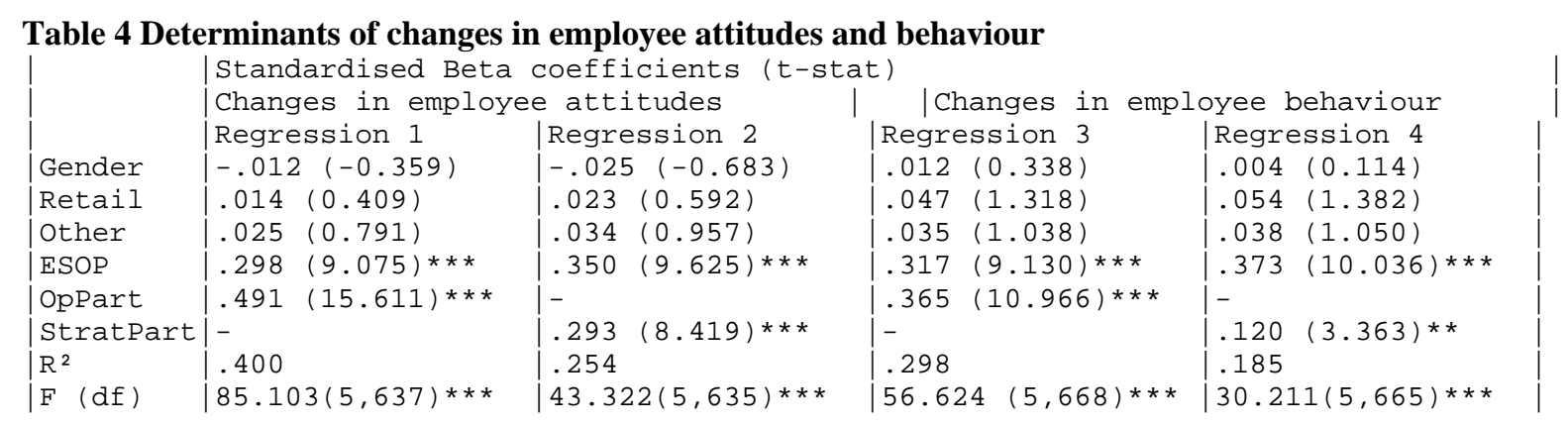

Note: *Significant at $0.05, * *$ Significant at $0.01, * * *$ Significant at 0.001

Regression 1 indicates that a change in employee participation at the operational level has the most statistically significant impact on employee attitudes $(S ?=.491)$. Departmental/strategiclevel participation also has a significant and positive, if weaker $(S ?=.293)$ impact on employee attitudes (regression 2). Therefore, as predicted in our model, an increase in employee participation is associated with improved employee attitudes towards the firm and its management. This is particularly the case when employees feel they have greater say in decisions that effect their immediate work environment.

Both Regressions 1 and 2 also indicate a significant and positive relationship between changes in employee attitudes and ESOP membership $(\mathrm{S} ?=.298$ and .350$)$. This positive relationship indicates that ESOP members are more likely to report an increase in their commitment to the firm and its management, and provides support for the importance of employee participation and financial incentives in changing employee attitudes.

Regressions 3 and 4 report the relationship between the independent variables and changes in employee behaviour. Results are similar to those concerning employee attitudes, indicating that operational-level participation is the most significant variable in determining employee behaviour $(\mathrm{S} ?=.365)$, and ESOP membership also plays a significant role $(\mathrm{S} ?=.317$ and .373$)$. Although statistically significant, departmental/strategic participation plays a much less significant role in determining employee behaviour than employee attitudes $(S ?=.120)$.

Overall, these results support the proposition that the ESOP has a positive relationship with attitudes and behaviour through both the instrumental satisfaction route (employee participation) and the extrinsic satisfaction route (financial incentives). 


\section{Conclusions}

Much of the literature on employee share-ownership focuses on the relationship between ownership and performance outcomes, including employee attitudes and behaviour. The substantial and unparalleled size of the Eircom ESOP, presented an opportunity to conduct a robust test of these relationships in the context of a publicly-quoted firm.

Overall, results show a positive shift in attitudes and behaviour since the introduction of the ESOP. However the changes observed are not strong, particularly in relation to employee attitudes; a finding that is somewhat surprising given that the ESOP controls 35 percent of firm equity. A number of reasons can be suggested for this less than dramatic impact on employee attitudes and behaviour.

Firstly, our survey findings indicate that the majority of employees do not associate the ESOP with an increase in worker participation in decision-making. The representative nature of the ESOP means that the day-to-day decisions are taken by the ESOP trust's board of directors, who are appointed by senior trade union officials, with little or no employee consultation. Furthermore, although the ESOP appoints three directors to Eircom's board, these directors have a fiduciary duty to protect the investment of all shareholders and cannot be used to promote employee welfare. Pendleton et al (1995) highlight the importance of identifying the rationale for establishing a ESOP when evaluating its outcomes. The primary objective of the Eircom ESOP was not to promote greater industrial democracy. Instead, it was established as a means of reducing employee opposition to privatisation and firm restructuring. As a result, many employees, trade unionists and managers may view the ESOP as primarily a financial benefit scheme, and not as a means of promoting a culture of cooperation in decision-making (Rosen et al., 1985; Wetzel et al., 1992).

Secondly, although the financial returns generated by the ESOP appear to have had a significant and positive impact on employee attitudes and behaviour, we suggest that the ESOP has not fulfilled its potential in this respect. Although substantial, the financial returns generated by the ESOP cannot be linked to changes in employee performance. Instead, it appears that increased returns have been 'pulled along' by reduced firm costs, as opposed to being 'pushed along' by the ESOP and the creation of greater employee performance (Blasi et al., 2003). As a result, it is difficult to see how the ESOP can provide employees with a clear line of sight between their work-effort and returns they receive. It is also important to note that because those employees who leave Eircom are allowed to maintain ESOP membership, almost 50 percent of the ESOP's participants are no longer employees of the firm. ESOP participants who are no longer employed by the firm may be expected to have little interest in the firm's long-term prospects.

The performance of Eircom as a privatised company has proved to be highly controversial, as the company has gone through three changes of ownership since privatisation and has failed to deliver on expectations of improved service-delivery. Ten years after full-privatisation the current Minister for Communications asserted that "We privatised a highly profitable, debt-free, heavily investing Eircom and the result on prices, services, and broadband has been disastrous" (Irish Times, March 18 ${ }^{\text {th }}$, 2009). The role of the ESOP in this process has attracted much debate and criticism. Sweeney (2004) concludes that the ESOP has allowed employees to gain financially in the short-term and has had great influence over firm governance and strategy. However it has not used this influence in the long-term interests of the firm or its employees. As many employees have been employed by Eircom for over 25 years, they take a great deal of pride in the public services the firm provides. For these employees, the ESOP's focus on creating short-term 
financial returns at the expense of long-term service quality may have created a sense of disappointment or even resentment.

Footnotes:

1. This research has been funded by the Irish Council for the Humanities and Social Sciences (IRCHSS).

2. A full participant will have given the firm one year of continuous service prior to the establishment of the ESOP

3. The ESOP held Vodafone ordinary shares because of the demerger and sale of the mobile subsidiary Eircell to Vodafone in 2001 by way of a share-swap

\section{Bibliography}

Ackers, P. and Payne, J. (1998), "British Trade Unions and Social Partnership: Rhetoric, Reality and Strategy", The International Journal of Human Resource Management, Vol. 9, No. 3, pp. 52950 .

Alchian, A. A. and Demsetz, H. (1973), "The Property Right Paradigm", The Journal of Economic History, Vol. 33, No. 1, pp. 16-27.

Beatty, R. P. and Zajac, E. J. (1994), "Managerial Incentives, Monitoring, and Risk Bearing: A Study of Executive Compensation, Ownership, and Board Structure in Initial Public Offerings", Administrative Science Quarterly, Vol. 39, No. 2, pp. 313-336.

Ben-Ner, A. and Jones, D. C. (1995), "Employee Participation, Ownership, and Productivity: A Theoretical Framework." Industrial Relations, Vol. 34, No. 4, pp. 532-555.

Blasi, J., et al. (2004), "Motivating Employee Ownership in ESOP Firms: Human Resource Policies and Company Performance", CEP Discussion Paper no.0658 [online], Centre of Economic Performance, available: http://cep.lse.ac.uk/_new/publications/series.asp?prog=CEP [accessed 18 Jan 2006].

Blasi, J., Conte, M. and Kruse, D. (1996), "Employee Stock Ownership and Corporate Performance Among Public Companies." Industrial \& Labor Relations Review, Vol. 50, No. 1, pp. 60-80.

Blasi, J., Kruse, D. and Bernstein, A. (2003), In the Company of Owners: The Truth about Stock Options (and Why Every Employee Should Have Them), Basic Books, New York.

Buchko, A. A. (1993), "The Effects of Employee Ownership on Employee Attitudes: An Integrated Causal Model and Path Analysis." Journal of Management Studies, Vol. 30, No. 4, pp. 633-658.

Conte, M. A. and Kruse, D. (1991), "ESOPS and Profit-Sharing Plans: Do They Link Employee Pay to Company Performance?" Financial Management, Vol. 20, No. 4, pp. 91-101.

D'Art, D. and Turner, T. (2006), "Profit Sharing and Employee Share Ownership in Ireland: A New Departure?" Economic and Industrial Democracy, Vol. 27, No. 4, pp. 543-564.

Freeman, R. B., Kruse, D. and Blasi, J. (2004), "Monitoring Colleagues at Work: Profit Sharing, Employee Ownership, Broad-Based Stock Options and Workplace Performance in the United 
States", CEP Discussion Paper no.647 [online], Centre for Economic Performance, available: http://cep.ise.as.uk/pubs/downloads/dp0647.pdf [accessed 16 Jan 2006].

Freeman, S. F. (2007), "Effects of ESOP Adoption and Employee Ownership: Thirty years of Research and Experience", Working Paper No. 07-01, University of Pennsylvania [online], available: http://www.aeoa.org.au/docs/0024/ESOPs\%2030\%20years\%20of\%20research..pdf [accessed 26 June 2009].

Gianaris, N. V. (1996), Modern Capitalism: Privatisation, Employee Ownership, and Industrial Democracy, Praeger Publishers, London.

Gittell, J. H., Von Nordenflycht, A. and Kochan, T. A. (2004), "Mutual Gains or Zero Sum? Labor Relations and Firm Performance in the Airline Industry." Industrial \& Labor Relations Review, Vol. 57, No. 2, pp. 163-180.

Grossman, S. J. and Hart, O. D. (1980), "Takeover Bids, the Free-Rider Problem, and the Theory of the Corporation." Bell Journal of Economics, Vol. 11, No. 1, pp. 42-65.

Hart, O. D. (1983), "Optimal Labour Contracts Under Asymmetric Information: An Introduction." Review of Economic Studies, Vol. 50, No. 160, pp. 03-36.

Hastings, T. (2003), "Making the Quantum Leap with an ESOP: Interview with Shay Cody", Labour Relations Commission Review, Vol. 1, No. Issue, pp. 5-7.

Jensen, M. C. and Murphy, K. J. (1990), "CEO Incentives: It's not How Much you Pay, but How." Harvard Business Review, Vol. 68, No. 3, pp. 138-154.

Kaarsemaker, E. C. A. and Poutsma, E. (2006), "The Fit of Employee Ownership with Other Human Resource Management Practices: Theoretical and Empirical Suggestions Regarding the Existence of an Ownership High-Performance Work System", Economic and Industrial Democracy, Vol. 27, No. 4, pp. 669-685.

Kalmi, P., Pendleton, A. and Poutsma, E. (2005), "Financial Participation and Performance in Europe", Human Resource Management Journal, Vol. 15, No. 4, pp. 54-67.

Kelly, J. (2001), 'Social Partnership Agreements in Britain: Union Revitalisation or Employer Counter Mobilisation', in M. M. Lucio and M. Stuart (eds.) Assessing Partnership: The Prospects for and Challenges of 'Modernisation', Leeds University Business School, Leeds, 79-86.

Klein, K. (1987), "Employee Stock Ownership and Employee Attitudes: A Test of Three Models", Journal of Applied Psychology, Vol. 72, No. 2, pp. 319-332.

Kochan, T. and Osterman, P. (1994), The Mutual Gains Enterprise, Harvard University Press, Boston.

Kruse, D., et al. (2004), 'Motivating Employee-Owners in ESOP Firms: Human Resource Policies 
and Company Performance', in V. Perotin and A. Robinson (eds.) Employee Participation, Firm Performance and Survival, Emerald, Bingley, 101-127.

Long, R. J. (1980), "Job Attitudes and Organizational Performance Under Employee Ownership." Academy of Management Journal, Vol. 23, No. 4, pp. 726-738.

Lucio, M. M. and Stewart, M. (2004), "Swimming Against the Tide: Social Partnership, Mutual Gains and the Revival of 'tried' HRM", International Journal of Human Resource Management, Vol. 15, No. 2, pp. 410-424.

Mathieu, M. (2007), "Annual Economic Survey of Employee Ownership in European Countries 2007", [online], European Federation of Employee Share Ownership, available: http://www.efesonline.org/ [accessed 19 Feb 2009].

NESC (1996) 'Strategy into the 21st Century', Report No. 98, Dublin: National Economic and Social Council.

O'Connell Davidson, J. (1993), Privatization \& Employment Relations: The Case of the Water Industry, Mansell Publishing Limited, London.

O’Donovan, P. (1999), 'A Trade Union Perspective', in B. Reynolds and S. Healy (eds.) Social Partnership in a New Century, Cori Justice Commission, Dublin,

Pendleton, A., McDonald, J., Robinson, A. and Wilson, N. (1995), "Patterns of Employee Participation and Industrial Democracy in UK Employee Share Ownership Plans", CEP Discussion Paper no.249 [online], Centre for Economic Performance, available: http://cep.ise.as.uk/pubs/downloads/dp0249.pdf [accessed 13 Sept. 2006].

Pendleton, A., Poutsma, E., Ommeren, J. V. and Brewster, C. (2001), "Employee Share Ownership and Profit-Sharing in the European Union", Report EF0156 [online], European Foundation for the Improvement of Living and Working Conditions, available: http://www.eurofound.europa.eu/publications/htmlfiles/el0156.htm [accessed 15th Jan 2006].

Pendleton, A., Wilson, N. and Wright, M. (1998), "The Perception and Effects of Share Ownership: Empirical Evidence from Employee Buy-Outs." British Journal of Industrial Relations, Vol. 36, No. 1, pp. 99-124.

Rooney, P. M. (1988), "Worker Participation in Employee-Owned Firms." Journal of Economic Issues, Vol. 22, No. 2, pp. 451-459.

Rosen, C. M. (2007), Employee Ownership and Corporate Performance: A Review of Research on U.S. Companies, National Centre for Employee Ownership, Oakland.

Rosen, C. M., Klein, K. J. and Young, K. M. (1985), Employee Ownership in America: The Equity Solution, Lexington Books, Lexington. 
Saunders, P. and Harris, C. (1994), Privatisation and Popular Capitalism, Open University Press, Buckingham.

Sesil, J., Kroumova, M., Blasi, J. and Kruse, D. (2002), "Broad-Based Employee Stock Options in US 'New Economy' Firms", British Journal of Industrial Relations, Vol. 40, No. 2, pp. 273-294.

Smith, A. (2009), "'Worky Tickets': Exploring Dissent at 'Work', Special 'Beyond the Control Resistance Debate: A Fresh Look at Experience of Work in the New Economy' Issue of ", Qualitative Research in Accounting and Management, Vol. 6, No. 1 and 2, pp. 14-25.

Stuart, M. and Lucio, M. M. (2005), 'Partnership and Modernisation in Employment Relations: An Introduction', in M. Stuart and M. M. Lucio (eds.) Partnership and Modernisation in Employee Relations, Routledge, London,

Sweeney, P. (2004), Selling Out? Privatisation in Ireland, New Island, Dublin.

Taylor, P. and Ramsay, H. (1998), "Unions, Partnership and HRM: Sleeping with the Enemy", International Journal of Employment Studies, Vol. 6, No. 2, pp. 115-143.

Telecom-Éireann (1997) 'The Telecom Partnership: A Framework Agreement for the Transformation of Telecom Éireann into a World Class Telecommunications Business', Dublin: Bord Telecom Éireann.

Wetzel, K., Gallagher, D. G. and Berg, S. (1992), "Union Commitment Among Cooperative and Private Sector Retail Workers", Annals of Public and Cooperative Economics, Vol. 63, No. 1, pp. $55-75$. 
Appendix 1 Descriptive statistics and correlation between variables

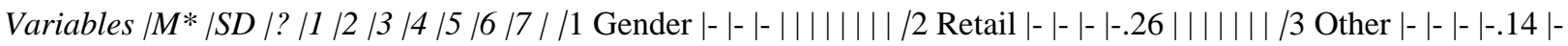

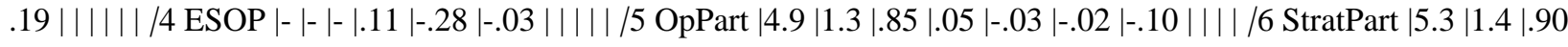

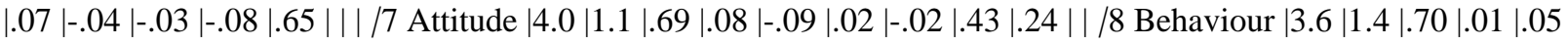
$|.02| .13|.31| .09|.57| \mid$ Note: $\mathrm{N}=711$, If $\mathrm{r}$ ? .08, $\mathrm{p}<.05 ; \mathrm{r} ? .12, \mathrm{p}<.01 ; \mathrm{r} ? .14, \mathrm{p}<.001$,

*mean values are based on each measure's original seven-point scale

[1] Corresponding author for purpose of chec?[pic]?[pic]?[pic]?[pic]?[pic]?[pic]?[pic]?[pic]?[pic]?[pic]?[pic]?[pic]?[pic]?[pic]?[pic]?[pic]? [pic]?[pic]?[pic]?[pic]?[pic]?[pic]?[pic]?[pic]?[pic]?[pic]ò?è?ß?ß?ß?ß?ß?Ú?ß?ß?ß?ß?ßking proofs and requesting a copy of the research instrument.

[2] Comsource was a consortium of the privatised Dutch telecom KPN and the Swedish stateowned telecom Telia. It invested $€ 232$ million in Telecom Éireann, in exchange for a 20 percent shareholding and an option to increase their stake by a further 15 percent

\author{
Financial \\ incentives
}

Employee participation

Employee Attitudes and Behaviour

Employee Share-Ownership Scheme 